\title{
Assessment of Government Internal Control Systems on Financial Reporting Quality in Ghana: A Case Study of Ghana Revenue Authority
}

\author{
Wonder Agbenyo ${ }^{1}$, Yuansheng Jiang ${ }^{1} \&$ Prince Komla Cobblah ${ }^{2}$ \\ ${ }^{1}$ College of Economics, Sichuan Agricultural University, Chengdu, China \\ ${ }^{2}$ Business School, University of Ghana, Legon, Ghana \\ Corresponding Author: College of Economicss, Sichuan Agricultural University, Chengdu 611130, China. Tel: \\ 86-157-0847-6521. E-mail: agbenyowonder@gmail.com
}

Received: September 1, 2018

Accepted: September 29, 2018

Online Published: October 20, 2018

doi:10.5539/ijef.v10n11p40

URL: https://doi.org/10.5539/ijef.v10n11p40

\begin{abstract}
Internal control systems cannot be underestimated as it serves as the lifeblood of most institutions in terms of its imperative roles that it plays in both tangible and intangible assets of an organization. Internal control actions on quality financial report state positive goals more especially when all parties involved adhere to their duties; thus, making the quality of financial reporting comparable, understandable, relevant, and reliable. In this regard, this study investigated the impact of government internal control systems on financial reporting quality in Ghana using Ghana Revenue Authority as the case study. Specifically, the study examined the nature and quality of financial reporting and the impact of government internal control systems on financial reporting quality. Both quota and simple random sampling techniques were used to select fifty (50) persons as the sample size of the study. Questionnaires were used to obtain data. The correlation matrix was used to examine the relationship between government internal control systems and financial reporting quality. The study finds out that contrary to apriori expectation sign monitoring as an element of internal control system has a negative impact on the financial quality reporting but was however statistically significant. The study also revealed that with a unit increase in the collection performance, the financial reporting quality of GRA will improve. The study recommended that the government should ensure that the internal control systems are well monitored and regulated.
\end{abstract}

Keywords: government internal control systems, financial reporting quality, Ghana revenue authority

\section{Introducation}

Internal control systems cannot be underestimated as it serves as the lifeblood for most institutions in terms of its imperative roles that it plays in both tangible and intangible assets of an organization. Internal controls suggest to the measures established by an organization in order to ensure that the aims, objectives and missions of the organization is ascertain (Brennan \& Soloman, 2008). They are frameworks of policies and procedures that ensure the assets of an organization, make reliable financial reporting, promote compliance with laws and regulations and ascertain effective and productive operations. However, in general, quality reporting process is influenced by an internal control system. There is a general discernment that institutions and implementation of proper internal control frameworks will dependably prompt to enhanced financial accomplishment. In the views of Gerrit and Mohammad (2010), the likelihood of achievement is affected by limitations inherent in all systems of internal control. Internal control actions on quality financial report state positive goals more especially when all the parties involve adhere to their duties; thus, making the quality of financial reporting comparable, understandable, relevant, and reliable. Emasu (2010) accentuates that organizations establish systems of internal control to help them improve their performance, achieve organizational goals, prevent loss of resources, enable production of reliable reports and ensure compliance with laws and regulations.

However, according to Barton (2009), information is often delayed, inaccurate and relayed from person to person rather than via reports, making it hard for the public sector to achieve financial reporting quality. Moreover, transparency of public company's operations, performance and strategic orientation for future, as well as the characteristics of their governance structures are becoming increasingly imperative topics to researchers. It is 
argued that organization without an internal control system in place is generally perceived to be open to risks that are capable of collapsing the institution in no time (Uwaoma \& Ordu, 2015). Uwaoma and Ordu (2015) further identify these risks to be: the risk of incorrect financial statement and/loss of the company's assets; stealing and miss-management of organizational vital documents which might be done by an employee to yield unwarranted advantage. Issues of incorrect and unreliable financial records are most common among public sectors over the world especially in developing countries among which Ghana is of no exception. It's emanated from this background that, there is the essence and urgency to investigate the influence of government internal control systems and financial reporting quality in Ghana focusing on Ghana Revenue Authority as a case study.

\subsection{Objectives of the Study}

The main objective of the study was to examine the impact of government internal control systems on financial reporting quality in Ghana, particularly the case of Ghana Revenue Authority (GRA). In order to attain the main objective of the study, the following specific objectives were formulated:

- To examine the nature and quality of financial reporting in the GRA of Ghana.

- To analyze the impact of government internal control systems on financial reporting quality.

\subsubsection{Conceptual Framework}

Fig.1 below gives a conceptual framework relating internal control systems to financial reporting quality. The free factors are internal controls and the system portray two components of internal controls, in particular, risk appraisal, control activities, control environment, information and communication, monitoring and collection performance all conceptualized to affect financial reporting quality. The dependent variable is the financial reporting quality which was measured regarding consistency with International financial reporting guidelines and dependability for its motivation. The framework additionally establishes that there are directing factors, for instance, regardless of the normal connection between internal controls and Financial Reporting Quality, hierarchical wastefulness can have an inverse impact. The conceptual framework has been deduced from the literature of various studies such as (Ofori, 2011; Hayes \& Baker, 2014; Abdi, 2015; Ibrahim, 2017) in relation to the topic in question.

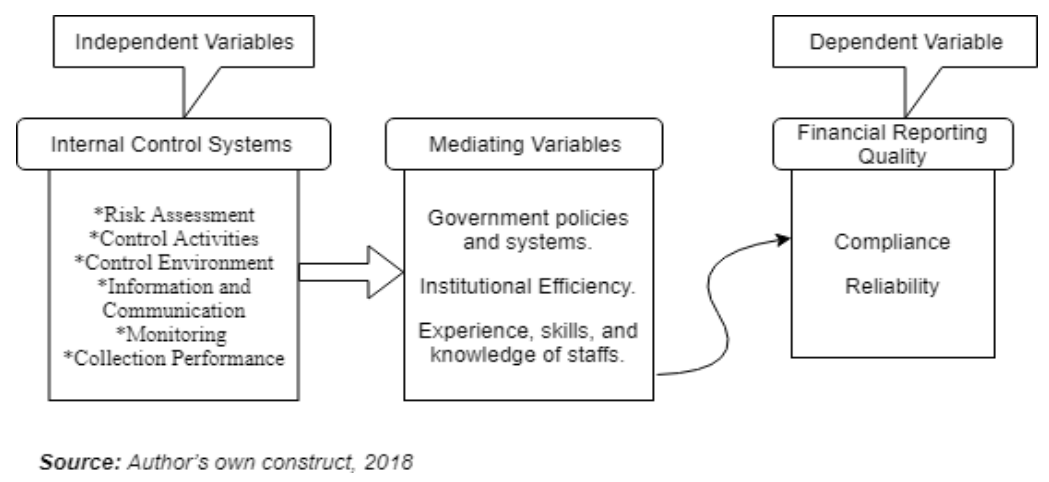

Figure 1. Relationship between government internal control systems and financial reporting quality

\section{Review of Related Literature}

\subsection{Agency Theory}

Agency theory depicts firms as essential structures to take care of agreements, and through firms, it is possible to rehearse control which limits adroit conduct of agents. Jensen and Meckling (1979) contend that, with the mean to fit the interests of the agent and the 13 principals, an understanding contract is formed to address the energy of both the principal and the agent. They additionally edify that the relationship is additionally fortified by the vital drawing in an expert to screen the agent. This position is likewise upheld by Coarse (1937) who keeps up that the agreement accommodates compromise between the agent and principal, the principal decides the work of an agent. He additionally recommends that the principal persists avoiding which denies him or her of benefitting from work by the agent. Nevertheless, the theory perceives the inadequate information about the relationship, interests or work execution of the agent portrayed as antagonistic determination and moral hazard. Coarse (1937) elucidates that moral hazard and adverse selection influences the yield of the agent in two different ways; not doing precisely what the agent is designated to do, and not having the fundamental information about what ought 
to be done. This, subsequently, influences the general execution of the relationship and additionally the advantages of the principal in form of money residual.

\subsection{Types of Internal Control}

In an investigation did by Abdi (2015) on the effect of internal control system on financial performance in Mogadishu Private Banks, he demonstrated that the rule of internal control put advances eight (8) sorts of internal control frameworks to be specific; organizational control, segregation of duties, physical control, personal control, supervision control, arithmetical and accounting control, authorization and approval and management control, approval and endorsement and administration control ought to be realistic in any organization or institutions. The Statement of Accounting Standards (SAS) moreover illuminates that internal control may be categorized as either accounting or administration controls. Accounting control focus on the plan of the institution and all the coordinated techniques and strategies which are realized with a point of view of protecting assets and updating the steadfastness of financial records. Management control includes the arrangement of the institution and all co-ordinates procedures and strategies that are concerned about operatically effectiveness an adherence to managerial approaches and mandates. Ofori (2011) depicted that internal controls are ordered basically into the control environment and control methods or exercises, Statement of Auditing Standards (SAS, 30). Be that as it may, Ibrahim (2017) have classified internal control into five parts which is the principle focal point of this paper. They are clarified beneath:

\subsubsection{Control Environment}

The control environment is the general control consciousness of an organization influenced by management through strategies, systems, ethical standards, and monitoring processes. This mirrors the top managerial staff and management firm choice to internal control. The control environment incorporates management theory found in its vision and mission for the organization. The components of the control environment likewise incorporate the authoritative structures which determine duty in the execution of financial and non-financial duties, management working style, state of mind, moral esteems, the integrity, ability and fitness of faculty.

\subsubsection{Control Activities}

Control activities are the procedures and strategies that help guarantee that management of an organization orders are passed on adequately and in a promising way (Ofori, 2011). These incorporate control activities, for instance, execution reviews, data preparing, physical controls, and confinement of commitments, these activities are completed by management to guarantee accomplishment of progressive objectives and the mitigations of hazard. As indicated by DiNapoli (2007), the control activities are the directions, principles, systems and decisions built up over various activities by management to foresee or reduce dangers that impact the association in achieving its objectives.

\subsubsection{Risk Assessment}

This is the procedure or techniques the organization goes through to distinguish and analyze the pertinent risks which may influence the organization's capacity to accomplish its significant targets. Risk appraisal includes utilizing proficient judgment deliberately in distinguishing and assessing factors which can influence the organization adversely and result in inconceivable misfortunes both financially and non-financially. According to Ofori (2011), this segment of internal control features the significance of management precisely recognizing and assessing factors that can block it from accomplishing its main goal. Risk appraisal is an efficient procedure for coordinating proficient judgment about plausible unfriendly environments and occasions and surveying the probability of conceivable misfortunes (financial and non-financial) resulting from their event.

\subsubsection{Information and Communication}

Information and communication are the bedrock of every effective business. Organizations with an absence of information and powerful communication will effortlessly fall in this 21 st century business environment. Effective communication within an organization empowers employees to endorse and prescribe internal control bearing on sensible execution which is utilized as a piece of the ordinary tasks of a business. Oberg and Walgenbach (2008) point out that if firm workers felt that they had gotten deficient or are not clear about internal control approaches declared by an organization they could maybe feel generally disappointed. This implies that when imperative information is concealed or withheld from employees, it could prompt disappointment among them thereby diminishing trust and efficiency inside the organization. Ofori (2011) contends that for the control system to be effective and efficient, there ought to be significant and dependable information which ought to be recorded and imparted to management and other staff within the organization. To complete the internal control and operational obligations and duties, the information ought to be auspicious and ought to go to the individuals 
who require it and in the correct frame. All workforce does comprehend their roles in the control framework, how their roles identify with others and their responsibility through the information and communication frameworks.

\subsubsection{Monitoring}

Monitoring is the appraisal of internal control execution over time; it is proficient by progressing monitoring activities and by isolated assessments of assistant control, for example, self-evaluations, peer reviews, and internal audits. The reason for monitoring is to decide if internal control is adequately designed, appropriately executed, and successful. Internal control is sufficiently planned and legitimately executed if each of the five internal control segments (Control Environment, Risk Assessment, Control Activities, Information and Communication, and Monitoring) are available and working as composed (Hayes \& Baker, 2014). Periodic evaluations of internal control are made and personnel, in carrying out their regular duties, obtain evidence as to whether the system of internal control continues to function. Management should implement internal control recommendations made by internal and independent auditors, corrects known deficiencies on a timely basis, and responds appropriately to reports and recommendations regulators.

\subsection{The Importance of Internal Controls}

Hay (1993) clarified internal control as "an entire system of control, financial and otherwise established by management with a specific end goal to carry on the business of the enterprise in a deliberate and successful way to guarantee adherence to administrative strategies and orders, safeguard the assets and ensure as far as possible the completeness and accuracy of the records, the prevention and identification of errors the fraud, and the convenient planning of financial information".

An organization's plan of internal control has a key role in the management of risks that are significant to the satisfaction of its business destinations. A sound plan of internal control adds to shielding the investors' investment and the organization's advantages. Internal control encourages the adequacy and productivity of operations, guarantees the dependability of internal and external reporting and helps consistency with laws and directions (Kochan, 1993). Effective financial controls, including the upkeep of legitimate accounting records, are an imperative component of internal control.

\subsection{Financial Reporting Quality}

As indicated by Cohen, Krishnamoorthy, and Wright, (2004), Chalmers and Godfrey (2004), a financial report is a method for depicting financial accountability. Evidence from the above scholars implies that for any institution that wants to survive in the competitive business environment have to make it a must to review their respective financial activities, prepare and publish their annual reports periodically and monitor their performance by comparing previous year performances to subsequent years. According to Barton (2009), and Horngren (2009), these are outputs of an accounting system and they are prepared at the end of the year, hence the name final accounts. According to Mattocks (2008), the financial reports ought to incorporate an account depiction of the organization's activities and inspected financial articulations. He contends that these empower the partners to see the organization's execution and the general financial circumstance of the organization.

\subsection{Internal Controls and Financial Reporting Quality}

Effective internal control over financial reporting ought to give sensible affirmation with respect to the unwavering quality of financial reporting and plan of financial explanations for external purposes. This activity gives sensible confirmation, both to management and investors, about the financial status of the organization. Sovereign governments additionally distribute their financial statements and these have far suggestions. The financial statements of sovereign governments affect their universal quality and are very significant in the present set of global business. Poor internal control is viewed as the essential motivation behind why extortion happens. Internal control and financial reporting have gotten expanded consideration particularly since the Tread way commission (1987) distinguished the tone set by senior management as the most critical factor adding to the honesty of financial reporting procedure (Sebbowa, 2009).

\subsection{Recent Empirical Reviews}

Khanna and Kaveri (2008) scrutinized the execution of risk-based internal audit in Indian Banks. To achieve the goals of the investigation, a structured questionnaire was sent to 43 banks in India, both in the public and private sectors to assist in data collection. 25 banks with 6 banks in the public and private sector respectively answered the questionnaire. The study portrayed that the banks have made satisfactory development in introducing risk-based internal audit. This refers to their understanding of approach for valuation of risk, audit procedures and execution of audit report. Rae and Subramaniam (2008) carried out a study on the quality of internal control 
procedures. The main objective of the study was on the antecedents and the moderating effect on organizational justice and employee fraud. The study gathers data from 64 Australian institutions. The study employed both logistic and multiple regression analysis to examine the moderating effect on organizational justice and employee fraud. The result revealed that the quality of internal control procedures has a moderating effect on the relationship between perceptions of organizational justice and employee fraud. They recommended that the risk management strategies relating to employee fraud need a critical attention.

In another investigation completed by Palfi and Muresan (2009) on the significance of an efficient system of internal control with respect to the bank sector. The sample depended on 25 credit organizations of Romania. The study of the review points out that the steady cooperation, in light of periodical gatherings, between all structures of the bank, portrays a viable internal audit department. Shanmugam, Haat and Ali (2012) also researched on the impact of internal control on the performance of small and medium enterprise. The study was carried out in Malaysia. They gathered data from their sample size using structured questionnaires. The study established that there is a significant relationship between the implementation of internal control and performance of SMEs.

Munene (2013), scrutinized the relationship between internal control frameworks and financial performance in Technical Training Institutions in Kenya. The investigation. The study aimed at the causes of tenacious poor financial performance from the point of view of internal controls. The study was directed utilizing both quantitative and qualitative methodologies utilizing survey, correlation and case study as research designs. The research revealed that there is a significant relationship between the internal control framework and financial performance. The study suggests that the institution should build and oversees manage information management system to empower all parties inside the organization to unreservedly get to and use the official information.

Most recently, Ibrahim (2017) investigated the internal control and public sector revenue generation in Nigeria. Both qualitative and quantitative technique was employed for the study. They gathered data from 38 respondents using a structured questionnaire. The study disclosed that the five components control environment, risk assessment, control activities, information and communication and monitoring must be available for internal controls to work as they are positively significant. He posits that there is a significant effect between internal controls and revenue collection in Federal Inland Revenue Service in Nigeria. The study suggests internal controls need to be adequately monitored in order to assess the quality and effectiveness of the system's performance over time.

\section{Study Methodology}

\subsection{Research Design}

In order to conduct a good analysis and achieve a realistic conclusion, data has been collected from two different sources. Thus, both primary and secondary sources. Osuala (2005) defined research design as the manner in which various components of a study are systematized in a comprehensible and reasonable way, hence, ensuring an effective approach of addressing the research problem. In this regard, the study employed the descriptive approach to examine the relationship of internal in this regard control and the quality of government financial reporting in Ghana focusing on GRA.

\subsection{Population and Sample Size of the Study}

The population of the study comprised all the internal auditors, accounts officers, management, finance officers, economists, and lawyers of the Ghanaian GRA. The target population of this study was estimated at six hundred and fifty-eight (658). Due to the nature of the study and a large number of the population, the researcher used both quota and simple random sampling techniques to select fifty-eight (58) persons as the sample size of the study. 58 questionnaires were distributed and 50 of them were retrieved.

\subsection{Data Source and Method of Data Collection}

The study adopted both primary and secondary data. The secondary data entails reviews from previous articles, reports and other relevant secondary materials in relation to the subject matter. A comprehensive questionnaire was designed to cover the objectives of the study as the primary data and was used to collect the data. The questionnaire was structured into three sections. The first section A sought to obtain demographic data about the respondents. Section B of the questionnaire focuses on the government internal control systems. The final section examines the financial reporting quality in GRA. They were measured on 5- point Likert- scale ranging from 1 (strongly agree) to 5 (strongly disagree). Table 1 below portrays the reliability test of the questionnaire that was administered. 
Table 1. Reliability statistics

\begin{tabular}{cc}
\hline Cronbach's Alpha & No: of Items \\
\hline .974 & 44 \\
\hline
\end{tabular}

Source: Researcher's Field Data, 2018.

\subsection{Methods of Data Analysis}

Data were collected and processed from various sources using the chosen data collection instruments. The questionnaires, which were answered by the respondents were tabulated and data analyzed by using descriptive, inferential and quantitative analytical techniques with estimations from the Gnu Regression, Econometrics and Time-series Library (Gretl) software. Statistical tools such as frequency distribution tables were employed in analyzing the questionnaire. This study employed the ordinary least squares multiple regression econometric model in estimating the study. The multiple regression model is specified as follows:

$$
\begin{gathered}
F R Q=\beta_{0}+\beta_{1} R A+\beta_{2} C A+\beta_{3} C E+\beta_{4} I C+\beta_{5} M+\beta_{6} C P+\varepsilon \\
\text { for } \beta_{i}>0
\end{gathered}
$$

Where FRQ indicates Financial Reporting Quality; RA represents risk assessment as an element of government internal control systems, CA denotes the control activities of government internal control systems, CE also represents the control environment activities of government internal control system, IC is the information and communication element of government internal control systems, $\mathrm{M}$ is the monitory element of the government internal control system and $\mathrm{CP}$ represents the Collection performance of government internal control system. $\beta_{\mathrm{i}}$ represents the coefficients of the independent variables, and $\beta_{0}$ is the constant term.

\section{Empirical Results and Discussions}

\subsection{Socio-Economic Demographic Characteristics of Respondent's}

The socio-economic demographic characteristics of the respondents are summarized in Table 1.

\begin{tabular}{|c|c|c|c|}
\hline & & $\mathbf{N}$ & $\%$ \\
\hline \multirow{3}{*}{ Gender } & Female & 18 & 36.0 \\
\hline & Male & 32 & 64.0 \\
\hline & Total & 50 & 100 \\
\hline \multirow{4}{*}{ Age group } & Below 20 years & & - \\
\hline & 20-35 years & 34 & 68.0 \\
\hline & 36-65 years & 16 & 32.0 \\
\hline & Total & $\mathbf{5 0}$ & 100.0 \\
\hline \multirow{5}{*}{ Level of Education } & High School Graduate & - & - \\
\hline & Undergraduate & 2 & 4.0 \\
\hline & Post Graduate & 39 & 78.0 \\
\hline & $\underline{\mathrm{PhD}}$ & 9 & 18.0 \\
\hline & Total & 50 & 100.0 \\
\hline \multirow{5}{*}{ Marital Status } & Single & 39 & 78.0 \\
\hline & Married & 11 & 22.0 \\
\hline & Divorced & - & - \\
\hline & Widow & - & - \\
\hline & Total & 50 & 100.0 \\
\hline \multirow{5}{*}{ Occupation } & Dep. Minister & - & - \\
\hline & Directors & 9 & 18.0 \\
\hline & Supervisors & 3 & 6.0 \\
\hline & Workers & 38 & 76.0 \\
\hline & Total & 50 & 100.0 \\
\hline
\end{tabular}

Table 2. Socio-economic demographic characteristics of respondents

Source: Researcher's Field Data, 2018.

\subsubsection{Gender of Respondents}

Table 2 gives the statistical evidence of the gender distribution for the study. Apparently, $32(64 \%)$ of the 
respondents were males, while $18(36 \%)$ were females. The finding indicates that variably majority of the study respondents are males. Eerily, $68 \%$ majority of the respondents aged between $20-35$ years and only $32 \%$ are aged between 36-65 years. The study also explored the educational background of respondents and it has been portrayed that majority of $39(78 \%)$ as Post graduates. Doctorial graduates followed closely with $9(18 \%)$. Respondents with first degree holders secured 2(4\%). The study discovered that 39(78\%) of the respondents indicated that they were singles, whilst $11(22 \%)$ said they have married. This clearly shows that majority of the respondents were single. As shown in Table 1 above. In conclusion to the general background of the respondents, $18 \%$ (9) of the respondents indicated that they are Directors, another set of respondents 6\% (3) also expressed that they are supervisors. Out of the 50 respondents interviewed; 76\% (38) were workers as well. None of the respondents were Deputy Minister at the time this study was conducted.

\subsection{Multiple Regression Results and Analysis}

\subsubsection{Analysis of Variance (ANOVA)}

This analysis was done to determine the fitness of the regression model using the F-Statistic, and the results for the analysis of variance are presented in Table 3 .

Table 3. Results for the analysis of variance

\begin{tabular}{lccc}
\hline & Sum of squares & Degree of freedom & Mean square \\
\hline Regression & 3803.56 & 6 & 633.926 \\
Residual & 413.561 & 43 & 9.6177 \\
Total & 4217.120 & 49 & 86.0637 \\
\hline $\mathrm{R}^{\wedge} 2=3803.56 / 4217.12=0.901933$ & & & \\
$\mathrm{~F}(6,43)=633.926 / 9.6177=65.9125$ [p-value 4.51e-020] & & \\
\hline
\end{tabular}

Hypothesis of testing the model fitness

$H_{0}$ : The model does not fit well the dataset.

$H_{1}$ : The model fit well the dataset.

Considering the p-value (0.000) of the F-statistic (65.9125), the multiple regression was found to be significant at $5 \%$. This implies that there is enough evidence to reject the null hypothesis that model is not well fit for the dataset; hence suggesting that the model best fit the dataset used in this study.

\subsubsection{Empirical Relationship between GRA's Internal Control System and Financial Reporting Quality}

This section addresses the relationship between the relationship of government internal control systems and financial reporting quality in Ghana focusing on the GRA as a case study. The results obtained in Table 4 indicate that there is a strong relationship $(\mathrm{r}=0.907 ; \mathrm{P}<0.01)$ between internal control systems and financial reporting quality. The relationship is also significantly positive indicating that implementation of government internal controls significantly ensures the quality of financial reports on the operations of the GRA. This result confirms the studies conducted by Bbosa (2011) and Widyaningsih (2015) which suggest that there exists a strong positive and significant relationship between internal control systems and financial reporting quality. Effectiveness of internal control systems is a mechanism for building high quality financial reporting.

Table 4. Relationship between GRA's internal control systems and financial reporting quality

\begin{tabular}{lcc}
\hline Variables & Internal Control Systems & Financial Reporting Quality \\
\hline Internal Control Systems & 1.00 & \\
Financial Reporting Quality & $0.907^{* *}$ & 1.00 \\
\hline
\end{tabular}

Note. ${ }^{* *}$. Correlation is significant at the 0.01 level (2-tailed).

Source: Field Survey, 2018. 
Table 5. Descriptive statistics and correlation matrix results

\begin{tabular}{|c|c|c|c|c|c|c|c|}
\hline \multicolumn{8}{|c|}{ Descriptive Statistics } \\
\hline Statistics & FQR & $\mathbf{R A}$ & $\mathbf{C A}$ & CE & IC & $\mathbf{M}$ & $\mathbf{C P}$ \\
\hline Observation & 50 & 50 & 50 & 50 & 50 & 50 & 50 \\
\hline Mean & 21.24 & 12.02 & 13.08 & 9.64 & 11.12 & 10.56 & 7.92 \\
\hline Std. Deviation & 9.28 & 3.87 & 3.05 & 3.53 & 3.37 & 3.38 & 2.45 \\
\hline Minimum & 11.00 & 6.00 & 6.00 & 5.00 & 6.00 & 5.00 & 4.00 \\
\hline Maximum & 41.00 & 20.00 & 19.00 & 18.00 & 19.00 & 18.00 & 12.00 \\
\hline \multicolumn{8}{|l|}{ Correlation Matrix } \\
\hline Variables & FQR & $\mathbf{R A}$ & CA & $\mathbf{C E}$ & IC & $\mathbf{M}$ & $\mathbf{C P}$ \\
\hline FRQ & 1 & & & & & & \\
\hline RA & $.884^{* *}$ & 1 & & & & & \\
\hline $\mathrm{CA}$ & $.719^{* *}$ & $.725^{* *}$ & 1 & & & & \\
\hline $\mathrm{CE}$ & $.608^{* *}$ & $.601^{* *}$ & $.675^{* *}$ & 1 & & & \\
\hline IC & $.836^{* *}$ & $.831^{* *}$ & $.723^{* *}$ & $.738^{* *}$ & 1 & & \\
\hline M & $.871^{* *}$ & $.764^{* *}$ & $.601^{* *}$ & $.723^{* *}$ & $.792^{* *}$ & 1 & \\
\hline $\mathrm{CP}$ & $.837^{* *}$ & $.841^{* *}$ & $.788^{* *}$ & $.464^{* *}$ & $.764^{* *}$ & $.679^{* *}$ & 1 \\
\hline
\end{tabular}

**. Correlation is significant at the 0.01 level (2-tailed).

Source: Field Survey, 2018.

Table 5 above provides the results of the descriptive statistics and the correlation matrix of the study. It consists of 50 observations representing the total number of people who participated in the study from the Ghana Revenue Authority. The standard deviation of the variables indicates variation or deviation of the variables from their mean values. All the variables portrayed little deviation from the mean values. This is because the degree of deviation from the mean value is not significant for the variables namely; Financial Report Quality, Risk Assessment, control activity, control environment, information and communication, monitoring and collection performance for Ghana Revenue Authority.

The correlation matrix on the other hand served as the testing of the relationship between risk assessment, control activities, control environment, information and communication, monitor and collection performance and financial reporting quality of Ghana Revenue Authority. It was done through the estimation of Pearson correlation coefficients between risk assessment and financial reporting quality of the GRA. As evident from the testing of the relationship from the table above it would be affirmed that most of the variables have the strong correlation coefficient above $(r=0.600)$ and are all significant $(\mathrm{Sig}=0.000: \mathrm{p}<0.01)$ which implies that there is a strong positive relationship between the variables (risk assessment, control activities, control environment, information and communication, monitor and collection performance of internal control system and financial reporting quality of GRA). The test portrays that the relationship between the variables is positive indicating that any $1 \%$ significant change positive or negative of risk assessment, control activities, control environment, information and communication, monitor and collection performance of the internal control system there will be corresponding $1 \%$ significant change in the financial reporting quality of the GRA.

According to Dittenhofer (2001), financial statement is an important component to create financial accountability which is a measure of financial performance of an organization. Kateeba (2010) also states that, financial accountability relates positively to the quality of financial statements. A comprehensive presentation of financial statements facilitates the creation of transparency and accountability. This will increase the transparency and public accountability. In the short sum, the study found that all the elements of internal control systems are positively correlated with financial reporting quality at the $1 \%$ level of significance. Also, all the elements variables are positively correlated to one another at the $1 \%$ level of significance.

The study further inquired the impacts of the various elements of internal control systems on the financial reporting quality. Table 6 presents the impact of the elements of internal control systems such as risk assessment, control activities, and information and communication on financial reporting quality in Ghana. The results presented in Table 6 exhibit the multiple regression model of the relationship between the elements of internal control and the quality of financial reporting. 
Table 6. Multiple regression results

\begin{tabular}{|c|c|c|c|c|}
\hline \multicolumn{5}{|c|}{$\begin{array}{c}\text { Model 1: OLS, using observations 1-50 } \\
\text { Dependent variable: Financial Reporting Quality }\end{array}$} \\
\hline & Coefficient & Std. Error & t-ratio & p-value \\
\hline Const & 1.98154 & 0.600882 & 3.298 & $0.0020 * * *$ \\
\hline $\mathbf{R A}$ & 0.264843 & 0.138927 & 1.906 & $0.0633 *$ \\
\hline $\mathbf{C A}$ & 0.160890 & 0.257989 & 0.6236 & 0.5362 \\
\hline $\mathbf{C E}$ & -0.189662 & 0.155919 & -1.216 & 0.2305 \\
\hline IC & 1.35918 & 0.166531 & 8.162 & $<0.0001 * * *$ \\
\hline $\mathbf{M}$ & -0.638915 & 0.273766 & -2.334 & $0.0243 * *$ \\
\hline $\mathbf{C P}$ & 1.49416 & 0.206504 & 7.235 & $<0.0001 * * *$ \\
\hline Mean dependent var & 21.24000 & & S.D. dependent var & 9.277051 \\
\hline Sum squared resid & 413.5611 & & S.E. of regression & 3.101242 \\
\hline R-squared & 0.901933 & & Adjusted R-squared & 0.888249 \\
\hline $\mathrm{F}(6,43)$ & 65.9125 & & P-value(F) & $4.51 \mathrm{e}-20$ \\
\hline Log-likelihood & -58.49175 & & Akaike criterion & 130.9835 \\
\hline Schwarz criterion & 144.3677 & & Hannan-Quinn & 136.0803 \\
\hline
\end{tabular}

Note. Dependent Variable: FRQ $* * *, * *$ and $*$ denote $1 \%, 5 \%$ and $10 \%$ significant level respectively.

From the results of the multiple linear regression displayed in Table 6 , the coefficient of determination $\mathrm{R}^{2}(0.902)$ indicates that $90.2 \%$ of the variations in the dependent variable (financial reporting quality) is explained jointly by the independent variables (risk assessment; control activities; control environment; and information and communication; monitor and collection performance of internal control system). The study found that the risk assessment as an element of internal control system has a significant and positive influence of the quality of financial reporting. This result was found a significant at $10 \%$ level of significant. With its coefficient of 0.265 , a $10 \%$ improvement in risk assessment of accounting information will result in $0.27 \%$ enhancement in the quality of financial reporting. This implies that risk assessment of internal control system is significant determinant of financial reporting quality in Ghana Revenue Authority. Also, the study portrayed that control activities of internal control system related positively to the quality of financial reporting but is not statistically significant. The study further observed that control environment has a negative influence on quality of financial reporting and is also not statistically significant.

The study further revealed that with a unit increase in the flow of information and effective communication will cause the quality of financial reporting to improve by $1.36 \%$, holding all the other factors constant. This result indicates that there is sufficient evident to suggest that the coefficient of information and effective communication is significant in predicting the quality of financial reporting in the Ghana Revenue Authority. The study again finds out that contrary to apriori expectation sign monitoring as an element of internal control system has a negative impact on the financial quality reporting but was however statistically significant at 5\%. However, from the correlation matrix in Table 5 above, portrayed that there is a strong positive relationship between control environment and monitoring. This suggest that the negative impact on the financial quality reporting in GRA was a result of weak control environment as an element of internal control. Finally, the study asserted that a unit increase in the collection performance will cause the quality of financial reporting to improve by $1.49 \%$, holding all the other factors constant. This result indicates that there is sufficient evident to suggest that the coefficient of collection performance is significant in predicting the quality of financial reporting in the GRA.

\section{Conclusion and Policy Recommendations}

The study assessed government internal control systems on the financial reporting quality in Ghana particularly Ghana Revenue Authority a significant public enterprise for the Ghanaian economy. Based on the data obtained, and the findings stipulated, the researchers concluded that internal control plays a vital role and further has positive impact on financial reporting quality more especially when all of the parties involved adhere to the objectives of the public financial management in Ghana. Most foreign internal control mechanisms have proven positive to the financial reporting quality thus given a clearer picture of countries' economies and making inform decision, and minimizing corruption. The study concludes that adherent to the objective of internal control policies should be the goal to yield financial reporting quality for productivity and reliability. The findings of the study fall in line with prvious studies conducted by (Bbosa, 2011; Haat \& Ali, 2012; Munene, 2013; Widyaningsih, 2015; Abdi, 2015 and Ibrahim, 2017). Based on the findings of the study, the researcher suggests 
the following policy recommendations to the GRA in order to ensure effective government internal control systems on its financial reporting. The GRA should develop a mechanism to incorporate relevant feedback from the various stakeholders into their internal control system. The study further recommends that the government should ensure that the internal control system is periodically monitored and evaluated. The actual assessment can be executed by the organization's management. GRA should develop and organize constant seminars and workshops to train and educate auditors and accountants on matters pertaining proper implementation of accounting policies and procedures to enhance their skills and expertise in their practice as professionals which will strengthen the control environment. GRA should transparently report on the structure and performance of their governance, risk management, and internal control system in their various reports to internal and external stakeholders, such as through their periodic accountability reports or on the organization's website.

\section{References}

Abdi, A. D. (2015). The Impact of Internal Control System on Financial Performance In Mogadishu Private Banks (Case Study Some Selected Private Banks In Mogadishu). Doctoral dissertation, Master's Thesis. Horseed International University.

Barton, A. (2009). The use and abuse of accounting in the public sector financial management reform program in Australia. Abacus, 45(2), 221-248. https://doi.org/10.1111/j.1467-6281.2009.00283.x

Bbosa, E. (2011). Internal Controls and the Quality of Financial Statements in Local Governments Case Study: Wakiso District. Unpublished Dissertation Submitted to Makarere University.

Brennan, N. M., \& Solomon, J. (2008). Corporate governance, accountability and mechanisms of accountability: An overview. Accounting, Auditing \& Accountability Journal, 21(7), 885-906. https://doi.org/10.1108/09513570810907401

Chalmers, K., \& Godfrey, J. M. (2004). Reputation costs: the impetus for voluntary derivative financial instrument reporting. Accounting, Organizations and Society, 29(2), 95-125. https://doi.org/10.1016/S0361-3682(02)00034-X

Coase, R. H. (1937). The nature of the firm. Economica, 4(16), 386-405. https://doi.org/10.1111/j.1468-0335.1937.tb00002.x

Cohen, J. R., Krishnamoorthy, G., \& Wright, A. (2004). The corporate governance mosaic and financial reporting quality.

DiNapoli, T. P. (2007). Standards for internal control. Retrieved from http://www.osc.state.ny.us/agencies/ictf/docs/intcontrol_stds. pdf

Dittenhofer, M. (2001). Internal auditing effectiveness: an expansion of present methods. Managerial Auditing Journal, 16(8), 443-450. https://doi.org/10.1108/EUM0000000006064

Emasu, S. (2010). Public Financial Management: Concepts and Practices.

Gerrit, S., \& Mohammad, J. A. (2010). Monitoring effects of the internal Audit Function: Agency Theory versus other explanatory variables. International Journal of Auditing.

Hay, D. (1993). Internal control: How it evolved in four English-speaking countries. The Accounting Historians Journal, 79-102. https://doi.org/10.2308/0148-4184.20.1.79

Hayes, R. S., \& Baker, R. (2014). A participant observation study of the resolution of audit engagement challenges in government tax compliance audits. Qualitative Research in Accounting \& Management, 11(4), 416-439. https://doi.org/10.1108/QRAM-02-2013-0003

Horngren, C. T. (2009). Cost accounting: A managerial emphasis. Pearson Education India.

Ibrahim, M. (2017). Internal Control and Public Sector Revenue Generation in Nigeria: An Empirical Analysis.

Jensen, M. C., \& Meckling, W. H. (1979). Theory of the firm: Managerial behavior, agency costs, and ownership structure. In Economics social institutions (pp. 163-231). Springer, Dordrecht. https://doi.org/10.1007/978-94-009-9257-3_8

Kateeba, P. M. G. (2010). The Relationship between Governance and Quality of Financial Reports in NGOs (Doctoral dissertation, Makerere University).

Khanna, V. K., \& Kaveri, V. S. (2008). Implementing Risk-Based Internal Audit in Indian Banks: An Assessment of Organizational Preparedness. The IUP Journal of Bank Management, 7(3), 23-47.

Kochan, A. (1993). Internal evaluations. The TQM Magazine, 5(2). https://doi.org/10.1108/EUM0000000003063 
Mattocks, R. (2008). The Zone of Insolvency: How Nonprofits Avoid Hidden Liabilities \& Build Financial Strength. John Wiley \& Sons.

Munene, M. J. (2013). Effect of internal controls on financial performance of technical training institutions in Kenya. An un-published masters dissertation.

Oberg, A., \& Walgenbach, P. (2008). Hierarchical structures of communication in a network organization. Scandinavian Journal of Management, 24(3), 183-198. https://doi.org/10.1016/j.scaman.2008.03.011

Ofori, W. (2011). Effectiveness of internal controls: a perception or reality? The evidence of Ghana Post Company Limited in Ashanti region (Doctoral dissertation).

Palfi, C., \& Muresan, M. (2009). Survey on weaknesses of banks internal control systems. Journal of International Finance and Economics, 9(1), 106-116.

Rae, K., \& Subramaniam, N. (2008). Quality of internal control procedures: Antecedents and moderating effect on organizational justice and employee fraud. Managerial Auditing Journal, 23(2), 104-124. https://doi.org/10.1108/02686900810839820

Sebbowa, B. B. K. (2009). The Role of Internal Audit Function in Organizations.

Shanmugam, J. K., Haat, M. H. C., \& Ali, A. (2012). An exploratory study of internal control and fraud prevention measures in SMEs. Small, 100, 18-2.

Uwaoma, I.,\& Ordu, P. A. (2015). The Impact of International Controls on Financial Management. A Case of Production Companies in Nigeria. International Journal of Economics, Commerce and Management, 3(12), 103-139.

Widyaningsih, A. (2015). The influence of internal control system on the financial accountability of elementary schools in Bandung, Indonesia. Research Journal of Finance and Accounting, 6(24), 89-96.

\section{Copyrights}

Copyright for this article is retained by the author(s), with first publication rights granted to the journal.

This is an open-access article distributed under the terms and conditions of the Creative Commons Attribution license (http://creativecommons.org/licenses/by/4.0/). 